\title{
A living light bulb, ultrasensitive biodetection made easy
}

\author{
Jing Shang and Xiaohu Gao*
}

\author{
Abstract \\ A team of scientists led by Professor DW Pang at Wuhan University have developed a new class of fluorescence \\ probes based on bacterial cells. These microbial factories manufacture semiconductor nanocrystals inside and \\ display protein A molecules on cell surface, transforming Staphylococcus aureus (S. aureus) cells into highly \\ fluorescent cellular beacons that can be easily adapted for detection of diverse biological targets.
}

\section{Commentary}

Semiconductor nanocrystals, commonly known as quantum dots (QDs), represent a new class of nanoprobes greatly advancing and expanding the capabilities of fluorescence imaging because of their superior electrical, optical, and structural properties compared to conventional fluorophores, such as size-tunable emission color, narrow and symmetrical emission peak, large absorption coefficient throughout a wide spectrum, outstanding brightness and photostability, and extremely large Stokes shift [1,2]. Furthermore, multicolor QDs can also serve as dopants in microspheres and nanospheres for optical barcoding and imaging signal amplification $[3,4]$.

Highly fluorescent and monodisperse QDs are often chemically synthesized via high-temperature organometallic procedure [5]. Recently, Dr. Pang's group at Wuhan University, China, has developed a very interesting approach by taming yeast cells into a living QD synthesizer [6]. Coupling yeasts' natural intracellular metabolic reaction of $\mathrm{Na}_{2} \mathrm{SeO}_{3}$ and detoxification of $\mathrm{Cd}$ ions, highly fluorescent CdSe QDs can be made with precisely controlled sizes and emission wavelengths. Regardless of the preparation procedure, however, the as synthesized QDs are subject to complex multistep processing, such as isolation, purification, functionalization with surface ligands, and conjugation with biomolecules (e.g., antibodies), before downstream bio-imaging and -detection applications can be realized.

\footnotetext{
* Correspondence: xgao@uw.edu

Department of Bioengineering, University of Washington, Seattle, WA 98195, USA
}

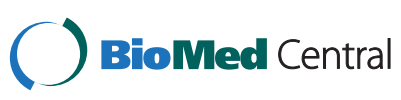

(c) 2014 Shang and Gao; licensee BioMed Central Ltd. This is an Open Access article distributed under the terms of the Creative Commons Attribution License (http://creativecommons.org/licenses/by/4.0), which permits unrestricted use, distribution, and reproduction in any medium, provided the original work is properly credited. The Creative Commons Public Domain Dedication waiver (http://creativecommons.org/publicdomain/zero/1.0/) applies to the data made available in this article unless otherwise stated.

To address this problem, in a recent publication in ACS Nano [7], Pang's group further advanced the microbial QD synthesizer using S. aureus cells, which can simultaneously produce highly fluorescent QDs inside and display Protein A on the cell surface. As a result, the whole bacterial cell is transformed into an ultrabright cellular beacon, with broad applications in ultrasensitive detection. Using pathogen detection as an example, they show detection sensitivity as low as $8.94 \mathrm{ng} / \mathrm{mL}$ (based on protein content).

The easy and sensitive detection is enabled by two key innovations. First, the application of whole cells as a fluorescent reporter eliminates the procedures for QD isolation and functionalization, which significantly simplifies assay preparation, Furthermore, the sandwich assay used in this paper maximizes the detection sensitivity by integrating the target enrichment capability of magnetic beads and signal amplification of cellular beacons [8].

Second, the protein A on S. aureus surface makes antibody conjugation easy. Through a simple mixing and incubation step, a variety of antibodies can be immobilized on the probe surface, enabling a broad application of the cellular beacon. It has been shown recently that although noncovalent, protein A - antibody binding is stable for at least a few hours $[9,10]$, which is sufficient for most biodetection assays.

In summary, the technology reported in this paper transforms cells into living light bulbs that can specifically highlight biological targets. The innovation and simplicity of this technology will stimulate further research on the use of live organisms for a wide spectrum of biomedical applications. 


\section{Competing interests}

The authors declare that they have no competing interests.

\section{Author's contributions}

JS and XHG wrote the article. All authors read and approved the final manuscript.

Received: 18 June 2014 Accepted: 18 June 2014

Published: 30 June 2014

\section{References}

1. Michalet X, Pinaud FF, Bentolila LA, Tsay JM, Doose S, Li JJ, Sundaresan G, Wu AM, Gambhir SS, Weiss S: Quantum dots for live cells, in vivo imaging, and diagnostics. Science 2005, 307:538-544.

2. Zrazhevskiy P, Sena M, Gao XH: Designing multifunctional quantum dots for bioimaging, detection, and drug delivery. Chem Soc Rev 2010, 39:4326-4354

3. Han MY, Gao XH, Su JZ, Nie S: Quantum-dot-tagged microbeads for multiplexed optical coding of biomolecules. Nat Biotechnol 2001, 19:631-635.

4. Yang J, Dave SR, Gao XH: Quantum dot nanobarcodes: epitaxial assembly of nanoparticle-polymer complexes in homogeneous solution. J Am Chem Soc 2008, 130:5286-5292.

5. Murray $C B$, Norris DJ, Bawendi MG: Synthesis and characterization of nearly monodisperse $\mathrm{Cde}(\mathrm{E}=\mathrm{S}$, Se, Te) semiconductor nanocrystallites. J Am Chem Soc 1993, 115:8706-8715.

6. Cui R, Liu HH, Xie HY, Zhang ZL, Yang YR, Pang DW, Xie ZX, Chen BB, Hu B, Shen P: Living yeast cells as a controllable biosynthesizer for fluorescent quantum dots. Funct Mater 2009, 19:2359-2364.

7. Xiong LH, Cui R, Zhang ZL, Yu X, Xie ZX, Shi YB, Pang DW: Uniform fluorescent nanobioprobes for pathogen detection. ACS Nano 2014, 8:5116-5124.

8. Nam JM, Thaxton CS, Mirkin CA: Nanoparticle-based bio-bar codes for the ultrasensitive detection of proteins. Science 2003, 301:1884-1886.

9. Zrazhevskiy P, Gao XH: Quantum dot imaging platform for single-cell molecular profiling. Nat Commun 2013, 4:1619.

10. Zrazhevskiy P, True LD, Gao XH: Multicolor multicycle molecular profiling with quantum dots for single-cell analysis. Nat Protoc 2013, 8:1852-1869.

doi:10.1186/2045-3701-4-34

Cite this article as: Shang and Gao: A living light bulb, ultrasensitive

biodetection made easy. Cell \& Bioscience 2014 4:34.

\section{Submit your next manuscript to BioMed Central and take full advantage of:}

- Convenient online submission

- Thorough peer review

- No space constraints or color figure charges

- Immediate publication on acceptance

- Inclusion in PubMed, CAS, Scopus and Google Scholar

- Research which is freely available for redistribution 